\title{
From the Editor-in-Chief
}

\author{
Kimon P. Valavanis
}

Published online: 20 February 2009

(C) Springer Science + Business Media B.V. 2009

\section{Dear Colleagues,}

We are well into the 2009 year; however, we have started planning for the years ahead. Thus, we are happy to report that effective January 2010, we will publish annually four Volumes of four issues each! That is, a total of 16 issues per year, the last issue of each Volume being a double issue.

This change has been dictated by the number of submitted papers. Even though there is no compromise on the quality - on the contrary, more papers are being rejected - we owe it to our readers and authors not to delay publication of accepted articles.

Indeed, the workload is much more, responsibilities are more, but we are all determined, the Springer team, the Editorial Board, Dina and I, to move forward.

I find this a great opportunity to thank, once more, the Springer team, Nathalie Jacobs, Anneke Pot, Gabriela DePoel and Joey Francis Magnata for their friendship and professionalism and dedication. On a personal note, since as they say I am not the easiest person to work with (I think I am, but this is a different story), I thank them for keeping up with me. Rest assure that the best is yet to come!

Enjoy the issue.

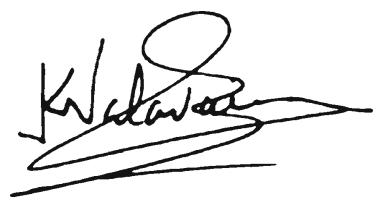

Kimon P. Valavanis

Editor-in-Chief

K. P. Valavanis $(\bowtie)$

Journal of Intelligent and Robotic Systems, Department of Electrical and Computer Engineering, School of Engineering and Computer Science,

University of Denver, Denver, CO 80208, USA

e-mail:kvalavan@du.edu, Kimon.Valavanis@du.edu 